\title{
ERNST BLOCH, FLLÒSOF, COM A MEDIEVALISTA \\ (A propòsit de la seva obra \\ Intermons en la història de la filosofia)
}

\section{Josep Manuel Udina i Cobo}

1. Com a bon filosof, Bloch va dedicar bona part de la seva atencí i del seu quefer filosòfics a la història de la filosofia ${ }^{1}$. I, alhora - com qualsevol altre bon filos of - , va subordinar la seva tasca d' historiador de la filosofia a la seva pròpia concepció filosòfica. La perspectiva corresponent, des de la qual abordava i jutjava els diferents pensadors o sistemes, és la perspectiva - típicament blochiana- que permet discernir-hi la presència, o l'absència, de petjades (indicis $\mathrm{i}$ anticipacions) de la "utopia concreta», d'una recerca insistent d'un futur nou, d'aquell encara no que resta efectivament present $\mathrm{i}$ actiu en la història (i, més en concret, en la història del pensament). Per a Bloch, la tasca de l'historiador de la filosofia només pot ser la del discerniment del futur en el passat, la d'obrir qualsevol moment

1 En la «Introducción al volum de les seves obres completes Zwischenwelten in der Philosophiegeschiche, Suhrkamp - Gesamtausgabe (GA) 12, Frankfurt del Main 1977, 342 p.: trad. cast.: Entremundos en la historia de la filosofia, Taurus — Ensayistaso 245-. Madrid 1984, 294 p. (dedicat explicitament a aquesta disciplina i que polaritza, per aixf dir-ho, el present article), Bloch mateix recorda els principals títols de la Gesamtausgabe en els quals ja havia fet una tasca equivalent; «Si 6 s possible, cal estalviar o reduir repeticions de tot allo que ja hem tractat historico-filosoficament en ocasió d'un o d'altre problemes, com és el cas de Demòcrit i la tradició dels materialistes, quant a El problema del materialisme, la seva història i substància, o la teoria estoica de la natura, quant a Dret natural i dignitat humana, i la teoria estoica del coneixement, quant a Experimentum muendi. En les obres completes tenim tambe extenses monografies d' historia de la filosofia, com per exemple el volum Subjecte-ob. jecte; aclariments al voltant de Hegel o bé, sota el títol de Avicenna i l'esquerra aristotelica —obra inclosa com a Apèndix del volum sobre El problema del materialisme esmentat-, el tractament de la filosofia medieval àrab i juevas, $Z W 17$ (15 s.); en endavant, $Z W$ abreuja Zwischenwelten in der Philosophiegeschichte, $\mathrm{i}$ tot seguit consignem la paginació i (entre parèntesis) les pàgines corresponents de la trad. cast, encara que la trad. de les citacions és feta sempre per nosaltres de l'alemany. 
-com a present de qualsevol temps, si fou un present autènticament fecund- a un vers endavant, a un anar sempre més enllà de si mateix ${ }^{2}$.

Com a testimoni, valguin sengles passatges de tres de les obres blochianes més característicament històrico-filosòfiques. El primer correspon al capítol final de Subjecte-objecte, el volum de Bloch dedicat a Hegel: «Els homes no som quelcom d'acabat, $\mathrm{i}$ així tampoc no ho és llur passat. Segueix aquest, sota altres signes, treballant amb nosaltres, en l'impuls de les seves preguntes, en l'experiment de les seves solucions. Tots anem en un mateix vaixell. Els morts retornen, transformats: aquells (com Thomas Müntzer) les gestes dels quals eren massa audaces perquè foren dutes a terme; aquells (com Ėsquil, el Dante, Shakespeare, Bach, Goethe) l'obra dels quals era massa vasta perquè coincidís amb el local de llur temps. Descobriment del futur en el passat: això és filosofia de la història i també, per tant, de la historia de la filosofias ${ }^{3}$. El segon fragment pertany a l'epígraf d'introducció de l'apassionat estudi biogràfico-filosòfic de Bloch sobre Th. Müntzer: «Volem restar només entre nosaltres. Ni tan sols aquí, doncs, no es dirigeix de cap manera el nostre esguard vers enrera. Més aviat ens barregem amb el passat d'una manera viva. I així també nosaltres retornem, transformats; els morts tornen a venir, i llurs fets volen acompanyar-nos de nou. [...] Müntzer és sobretot història en sentit fecund: ell, la seva obra $\mathrm{i}$ tot el pretèrit que mereix de ser consignat estan aquí per a obligar-nos, per a inspirar-nos, per a sostenir com més va més àmpliament el nostre constant proposito ${ }^{4}$. Quant a la darrera citació, és l'integre epígraf introductori de l'estudi de Bloch sobre Avicenna i la per ell anomenada esquerra aristotèlica: «Tot el que és assenyat pot haver estat ja pensat set vegades. Però sempre que ha estat de nou pensat, en un altre temps i unes altres circumstàncies, no era ja el mateix. No sols el pensador, sinó sobretot allò que s'ha de pensar, han canviat mentrestant. El que és assenyat, cal que s'hi acrediti de bell nou i per si mateix com a cosa nova. I és això el que

2 Bloch centra la seva més radical crítica a Hegel en el fet que aguest cau -com Platóen el que ell anomena *encís de l'anamnesi», és a dir: l'actitud de veure el filosofar com a esguard vers enrera o com a cre-flexiós sobre el passat i el ja esdevingut, sobre la realitat tal com de fet resta donada: vegeu Bloch, Subjekt-Objekt. Erlauterungen zu Hegel, Suhrkamp. GA 8. Frankfurt del Main 1962, p. $473-488$ (trad, cast., Sujeto-objeto. El pensamiento de Hegel, FCE, México-Madrid 1982, p. 439-451), cap. 23, «Hegel i l'anamnesi; contra l'encís de l'anamnesis.

${ }^{3}$ BLoCH, Subjekt-Objekt, ed. cit., p. 517 (trad, cit. p. 489 s.). Llevat de l'esmentat cap. 23 (afegit en l'ed. de l'obra en la GA), la primera elaboració del llibre es remunta al 1949, però - sencera- no apareix en alemany, sinó en cast. BLoCH, El pensamiento de Hegel. FCE, México-Madrid 1949.

${ }^{4}$ BLoCH, Thomas Muntzer als Theologe der Revolution Suhrkamp, GA 2, Frankfurt del Main 1969, p. 9 (trad. cast., Tomás Müntzer, teólogo de la revolución. Ciencia Nueva, Madrid 1968 - sobre una ed. prèvia a la GA: l'obra data de 1921 - p. 11). Subratllem: retormem. transformats, per remarcar la literalitat amb què l'autor volgué evocar en 1949 el passatge sobre Müntzer. 
s'esdevingué d'una manera particularment enriquidora entre els grans pensadors orientals, els quals salvaren $i$ alhora transformaren la llum gregass.

Com a síntesi aparentment críptica de les precedents formulacions, potser valdrà el lacònic incís blochià de la primera pàgina del llibre que polaritza el present article : «Allo que ha estat una vegada pensat fresquívolament, segueix rondant. ¿Com és que hom es meravella d'una cosa? que hom tan minsament s'hi entén? i que sempre sobrevé de re-pensar-la?" ${ }^{6} \mathrm{Si}$ el meravellar-se i l'admiració han estat des d'antic l'inici del filosofar - també, doncs, de la història de la filosofia-, no és menys cert per Bloch que la filosofia, i alhora l'esguard sobre la historia mateixa del filosofar, és sempre també un "re-pensar», una «re-flexió»: és un tornar a fer present el passat (aquell passat en el qual fou present el futur) o un tomar a la vida els morts (aquells morts que posseien la vida, per tal com restaren oberts al futur).

Aquesta és la perspectiva de Bloch, i és l'única que li interessa; la qual cosa no vol dir que sigui aquesta l'única perspectiva possible i legítima sobre el passat, sobre la història: això, mai no ho ha dit Bloch. També Hegel, per exemple, acceptava altres tipus d'història, d'historiografia; per bé que només li interessés veritablement la que ell anomenava ahistòria reflexiva ${ }^{7}$. No hem d'entrar, doncs, aquí, en la clàssica qüestió disputada (la qual divideix no menys clàssicament historiadors i filosofs) de si la historia és més afí a l'àmbit d'allo «científic» (en el sentit fort que el terme té popularment) o a l'àmbit de l'inevitablement afilosòfic» (no positiu, ni simplement quantificable, sinó més aviat subjectivo-interpretatiu).

Ens limitarem tanmateix a dir que veiem l'historiador com si estigués sobre la corda fluixa entre ambdues dimensions (la «científico-positiva», d'una banda, i la «filosòfico-interpretativa», d' una altra) i que considerem la cientificitat històrica com un ideal, al qual hom ha de tendir certament, però el qual hom mai no arribarà a assolir; car tampoc l'historiador no pot sortir fora de si mateix, no pot «saltar més enllà de la seva pròpia ombra» ni pot desprendre's de la seva «cosmovisió», de les seves preferències, dels

${ }_{5}^{5}$ BLoCH, Das Materialismusproblem, seine Geschichte und Substanz, Suhrkamp, GA 7, Frankfurt del Main 1972, p. 479. Del llibre original - recollit en la GA com a wapendixn de l'esmentat volum-: Avicena und die Aristotelische Linke, Aufbau, Berlín 1952 (hi ha trad. cast., Avicena y la izquierda aristotélica, Ciencia Nueva, Madrid 1966, 117 p., en la p. 9 de la qual es troba l'epigraf citat).

${ }^{6}$ BLOCH, ZW,9 (9). Traduïm I'alemany frisch com a «fresquívolaments per tal d'evocar el doble significat del terme original: per primera vegada, o amb vigoria. Qualsevol d'ambdues significacions val per al text.

${ }^{7}$ En Bloch, re-pensar i re-flexió podriem conjuntar-los en el terme alemany Nach-denken («pensar després d'haver pensatx), Quant a Hegel, en la $\alpha$ Introducción a les seves Llicons sobre filosofia de la historia universal distingeix entre «història immediatam $\mathrm{i}$ «historia reflexivas, i a més entre quatre tipus d'aquesta: història reflexiva «general», "pragmàtica», «criticas $\mathrm{i}$ «especials. 
seus judicis de valor (que són, doncs, «pre-judicis») més profunds. I és des d'aquesta convicció personal que ens apropem a Bloch i al seu fer història: història de la filosofia, concretament, i de la filosofia medieval, més en concret.

2. Bloch mai no ha estat advocat defensor de cap història "neutra», pretesament (pretenciosament?) objectiva $\mathrm{i}$ asèptica. La veritat - qualsevol veritat, també la veritat històrica - no és en Bloch, com tampoc en Hegel, cap moneda encunyada que hom tingui a la butxaca i en pugui disposar com d'una cosa fixa i llesta: la relació de l'home amb la veritat no és una relació amb cap cosa —relació que pogués ser freda i neutra-, sinó que és una relació compromesa, en la qual cal «prendre partit», cal comprometre's $\mathrm{i}$ decidir-se ${ }^{8}$. Adhuc la veritat marxista mateixa - que Bloch proclamà insistentment com a seva - no sols tenia, per a ell, un vessant "fred", estrictament analític, objectiu; tenia alhora un vessant «calid" - no menys decisiu $i$ important-, un vessant compromès $i$ anticipador, valent $i$ creador? I és per això que Bloch no podia sinó refusar amb tota fermesa qualsevol tipus de determinisme marxista, d'economicisme, de materialisme vulgar ${ }^{10}$. Però això tampoc no vol dir que la història de les idees no tingui res a veure amb la concreta realitat històrico-social $i$ econòmico-política en què aquestes idees sorgeixen i es desenvolupen, i sobre la qual

${ }^{8}$ Per a Bloch, la recerca de la veritat no admet restriccions prèvies: és necessari obrir-se a «tota l'herència culturals (Btoch, Philosophische Aufsaetze, Suhrkamp, GA 10, Frankfurt del Main 1969, p. 276, subratllat nostre; I'aportació a què pertany la frase $\longrightarrow$ Universitat, marxisme, filosofias, maig de 1949_, I'hem recollida a la nostra antologia: BLoCH, L'Are utopia-materia i altres escrits, Laia, Textos filosofics 37, Barcelona 1985, p. 113-147; vegen ibid., p. 123 i corresponent nota 14); no hi val, doncs, en aital recerca de la veritat, cap partidisme dogmàtic, ideologic, exclusivista. Pero alhora Bloch insisteix, en el mateix lloc, que tampoc no hi val cap actitud pretesament neutra, asèptica o eclectico-positivista, no val rebre aquesta therència» passivament $i$ indiferent: $a$ diferència de l'historicisme, és prendre una actitud viva i activa (ibidd.) allò que cal; la veritat és, doncs, una quiestió en la qual cal sempre prendre partit (i valgui quant a això recordar que la lliçó inaugural de Leipzig de 1949 . aquí citada, la recull Bloch en el corresponent volum de la $G$ A dins d'un conjunt d'aportacions titulat Ad Paedagogica: zur parteiischen Weisheit, és a dir: aAd paedagogica: per a una saviesa partidistan).

9 Vegeu BLoch, Das Prinzip Hoffrung, Suhrkamp, GA 5. Frankfurt del Main 1959, p. 224-258 (cap. 17 «El món en què la fantasia utòpica té un correlat»), i més en concret p. 235-242 (apartat aEl segons la possibilitat i l'ésser en possibilitat: corrents fred i calid en el marxismen) (trad. cast. El principio esperanza, Aguilar, Madrid 1977, vol. 1, p. 187-217 i 197-203; i trad, cat. L'arc utopia-matèrin i altres escrits, ed, cit., p. 149-206 i 169-179).

10 Com a pur exemple de citacions més a l'abast (entre els innombrables passatges que podriem adduir quant al tema), vegeu BLoCH, L'arc utopia-materia $i$ altres escrits, ed, cit., p. 127-132 (parlant del segon concepte fonamental del marxisme: la concepció econdmicodialectica de la historia) i p. 226-232 (apartat «El capgirament del dalt-baix i la seva mesuran), que corresponen respectivament a Philosophische Aufsaetze, ed. cit., p. 279-282, i a Tubinger Einleitung in die Philosophie, Suhrkamp, GA 13. Frankfurt del Main 1970, p. 198-202. 
acaben tanmateix incidint també activament, transformant-la. La relació entre les anomenades infrastructura i suprastructura (com la relació entre teoria i praxi) és una «inter-relació»: una relació mútua i de doble sentit, una relació dialèctica"

A l'hora de donar títol al volum de les seves obres completes dedicat precisament $i$ expressa a la història de la filosofia en general, Bloch escollia un terme prou significatiu: el de Zwischenwelten, «intermonsw. I tipificava així aquella presència de futur en el passat — d'un transcendir més enllà del present, més enllà d'allò donat- de la qual parlàvem: «L'interès d'aquest llibre rau als intermons de la historia de la filosofia. No cal dir que el concepte d'intermons res no té a veure aquí amb els àmbits intermundans en què Epicur situa els déus per tal de, tot separant-los del món, fer-los indiferents en llurs interespais. Tot el contrari: en la interveritat de què aquí es tracta, és quelcom de, a vegades, il-luminador el que s'hi troba, el que hom pot escoltar amb totes les orelles, el que es deixa sentir, el que comença a entrar en acció. Es tracta, doncs, de salvar un nou tipus de secundaritat que precisament res no té en comú amb cap mediocritat dels objectes. Aquí rauen tanmateix paradoxes com aquesta: algunes coses de la monumental Summa de Tomàs d'Aquino, com és ara la doctrina de l'adequació, semblen cridar-nos com des d'un racó com a secundaritat perduda $^{12}$. L'admirar-se comença de vegades a partir també d'objectes totalment diferents, de doctrines aparentment absurdes, però que de cap manera no s' esgoten en llur absurditat, sinó que indiquen un problema, com és ara el cas de l" "enrajolitzacióo" de Déu al portal de Betlem establerta per Occam com a possible de pensar-la ${ }^{13}$. I precisament des de la perspectiva

11 El que es diu de la interrelació d'infrastructura-suprastructura (en textos com els citats en la n. 10) val també per a la relació entre teoria i praxi. En el seu mateix títol, alhora, Subjecte-objecte apunta que aquest doble vessant és igualment questió central en Hegel. Més en concret, però, vegeu Das prinzip Hoffinung, ed. cit., p. 288-334 (cap. 19 «a transformació del món, o les Onze tesis de Marx sobre Feuerbachs) i sobretot p. 310-318 (apartat *Tesis 2 i 8, sobre teoria-praxi: prova i comprovaciós) (trad. cast., El principio esperamza, ed. cit., vol. I, p. 243-283 i sobretot p. 263-270).

12 Bloch al-ludeix a la teoria de la veritat com a adaequatio mentis ad rem, sobre la qual fa tota una exposició en el capitol dedicat a Tomàs d'Aquino. Vegeu BLoCH, ZW, 89.94 (76-81). La trad. cast. ha comès, però, el greu error (sols tipogràfic o fruit de voler corregir equivocadament l' autor?) de parlar de adoctrina de la educación» (trad. cit., p. 16), i no de ala adecuación:.

${ }^{13}$ Enrajolització de Déu tradueix Ziegelsteimwerdung Gottes, versió alemanya de l'expressió occamiana tegulafactio Dei. La idea d'Occam (com amplia Bloch mateix, en el cap. dedicat a Duns Scot i Occarn) és que hom podria establir com a possible que Déu hagués decidit que el Verb, en comptes de fer-se home (i néixer a l'establa de Betlem), s'hagués fet carn en forma d'un burret o d'un ase (com els del establa), i Déu fins i tot havia pogut venir al món en forma de rajola (també $n$ 'hi havia a l'establa!): «si així ho hagués volgut, hi hauria pogut tenir lloc aleshores, en comptes de l'encarnacio, una tegulafactio Dei, una enrajolització de Déu» (Bloch, ZW 118 s [102]). 
d'una crítica de la ideologia resten posades en relleu curioses excepcions de la dependència social del pensament, les quals es van anticipar a llur temps. En efecte: ¿què té a veure la teoria de la natura d'Escot Eriúgena amb els interessos ideologics del sacerdoci cristia del segle IX? o el nominalisme de Roscel-1f amb els interessos ideològics d'un feudalisme ja en formació? ${ }^{14}$

Bloch s'esforça, dones, a discernir missatge de futur $\mathrm{i}$ anticipació d'interès utòpic en racons doctrinals que semblen perduts, desatesos ordinàriament, però que no són simplement secundaris - ni indiferents a la realitat concreta on s'originen, ni mediocres-, sinó «accessoriss: és a dir, que hi accedeixen i s'hi esdevenen com «incidentalment», també «simultàniament» a altres doctrines o teories més comunament ateses i, en canvi, menys progressistes, més estancades en el passat deixant enrera, menys o gens obertes al futur, al vers endavant ${ }^{15}$. I es tracta alhora de racons doctrinals que de cap manera hom no pot sotmetre a la típica i tòpica crítica ideològica que redueix tants i tants continguts filosòfics a simple resultat de determinació social, d'interessos de classe o d'inevitable pensar a la manera d'un temps: això és, d'acord amb el «sentit comú» dominant en una època.

Seguint aquesta seva i ferma convicció -ni determinista o economicista, ni marxista vulgar o vulgar materialista - Bloch ja ens havia previngut en una altra ocasió (per cert, prou solemne i simptomàtica) contra les trivialitats, i també contra les explicacions reaccionàries i sentimentals, en què podem caure partint d'un malentès materialisme històric, esdevingut així vulgar ${ }^{16}$. Insistint ara en aquest punt, alhora ens diu tanmateix que el

I4 BLOCH, ZW, 18 (16 s). Quant a les dues darreres referències - de I'Eriúgena i Roscel$\mathrm{I}-$, vegeu $Z W, 63-68(54-57)$ i $68-70(58 \mathrm{~s})$, respectivament.

is L'adverbi nebenbei, que Bloch substantivitza, pot significar alhora: «secundàriaments, wincidentalment», aaccesscriament» $\mathrm{i}$ asimultàniament». Hem escollit «secundaritat» per a Nebenbei per afinitat amb altres termes: Nebenbedeutung (significació o importància secundaries), Nebenbegriff (idea o concepte secundaris), Nebenberuf (professí secundaria), Nebendarsteller (personatge secundari, comparsa, corista),

16 Vegeu Btoch, Philosophische Aufsaetze, ed. cit., p. 280 s. (Iliḉ̧ inaugural ja esmentada de 1949 (trad. cast. L'arc utopia-matèria $i$ altres escrits, ed. cit., p. 129): «S'han dit molts disbarats sobre la concepcí́ materialista de la història; el retret que se li fa es refereix al fet que aquesta concepció no deixa absolutament res més que els anomenats interessos materials més baixos i que no té cap sentit per a quelcom de superior. Dissortadament, el marxisme vulgar ha contribuit també a dir aquest disbarat; si hom en vol un exemple, això és pales pel que fa a la frase escandalosa del superat Kaustky: La Reforma no és res més que l'expressió ideológica dels canvis profund's operats en el mercat de llanes europeu. El marxisme vufgar. tanmateix, no és pas el marxisme: alhora, la fónnula emprada tan miserablement per Kaustky: no és res més que, s'avé d'una manera especialment dolenta amb el marxisme autèntic i científic, el qual reconeix a tot arreu efectes recíprocs, mediacions de vastes ramificacions entre infrastructura i suprastructura. (...) L'agudesa i la visió profunda del marxisme no $s^{\prime}$ avenen amb aquestes trivialitats. La critica marxista de la cultura burgesa és una cosa completament diferent d'una simple teoria econòmica i social; aspectes com aquests hi són 
seu interès, la seva perspectiva i la seva atenció quant a la filosofia medieval (no menys que quant a la resta de la hístòria del filosofar) tenen un caràcter ben determinat; $i$, per això mateix — hi haurem d'afegir-, prou limitat. És evident que n'hi ha d'altres, de perspectives $\mathrm{i}$ d'interessos possibles quant a això; ni llur existència ni llur legitimitat, no les podră negar Bloch. Però no és precisament en aquest sentit que l'autor reconeix la limitació del seu llibre; un llibre, diu, que no ofereix cap curs complet d'histò ria de la filosofia, car en aquell aquesta, com a tal, hi resta fragmentada, presentada intermitentment, a partir només de les parts més importants de l'Edat Mitjana i del Renaixement ${ }^{17}$. Ningú mai no té l'obligació de fer una obra que ho abasti tot; l'autor pot sempre delimitar l'àmbit del seu estudi. I, un cop delimitat aquest, l'obra de Bloch no ofereix precisament cap panoràmica (tant de l'Edat Mitjana, com del Renaixement) que puguem titllar simplement d'incompleta, almenys quant als autors seleccionats; més aviat, al contrari ${ }^{18}$.

La limitació que volíem destacar del llibre de Bloch, i de la qual l'autor sembla no voler adonar-se, és una limitació comuna a totes les obres (i a totes les parts - capítols o paràgrafs-d'obres) en què aquest fa d'historiador de la filosofia, una limitació pròpia de la seva peculiar perspectiva i dels seus interessos concrets: la limitació d'una perspectiva i d'un interès centrats únicament a discernir el futur en el passat, limitats exclusivament als aspectes «intermundans» de la història del filosofar. Com sempre en Bloch, el volum d'Intermons en la història de la filosofia ofereix un fer història del filosofar de manera parcial, i fins i tot partidista ${ }^{19}$. No més parcial ni partidista, aquí, pel fet que tingui la filosofia medieval com a

únicament subalterns. Per consegulent, tocant a l'autèntic rang i a la dignitat de la concepció dialèctico-materialista de la historia, no us deixeu enganyar per les explicacions reaccionàries i sentimentals que hom en faci; però tampoe per les explicacions de tipus marxista vulgar o materialista vulgaro (els darrers dos subratllats són nostres).

17 BLOCH, ZW, 17 y s. (16)

$18 \mathrm{Ni}$ fragmentària ni intermitent és, en efecte, una exposició del pensament medieval en la qual hom tracta d'Escot Eriúgena, Roscel-li, Anselm, Abelard, Albert Magne, Tomàs d'Aquino, Roger Bacon, Duns Escot, i Occam (vegeu BLOCH, ZW, 63-68 [54,57], 68-70 [58 i s.], 70-76 [60-65], 76-84 [66-72], 84-103 [73-88], 103-110 [89-94] i 110-134 [95-115]. respectivament; com també dels misties i dels moviments laies (vegeu ZW 135-163 [116138]), de Nicolau de Cusa (vegeu ZW, 63-72 [139-146]); i del métode escolàstic mateix, sobretot les summes (vegeu ZW, 55-63 [47-53]); i sense oblidar - com a precedentsTertul-lia i Origenes, d'una banda, i Agusti, d'altra (vegeu ZW, 36-43 [32-38] i 44-51 [39-44], respectivament).

${ }^{19}$ Emprem el terme en doble sentit: no sols el de l' exigència blochiana de cercar la veritat compromesament (vegeu supra, n.8), sin6 en el sentit quotidià i pejoratiu de parcialitat. subjectivitat. Quant a aix darrer, ja veurem (vegeu infra, n. 36-48) el tractament que Bloch fa d'Anselm i del seu кarguments, del qual no podia deixar de parlar si havia de referir-se a aquest pensador (en canvi, dissimuladament aconseguirà eludir de parlar de les $\alpha^{2}$ inc vies» de Tomàs d'Aquino, en abordar aquest autor: vegeu infra n. 39). 
objecte, sinó de la mateixa manera parcial i partidista com Bloch fa sempre historia del filosofar.

Precisament respecte a això som i haurem de ser crítics amb Bloch. Però alhora, la corresponent crítica mai no podrà ser tampoc una crítica absoluta; perquè en allò mateix en què sigui crítica haurà de comportar lloança i reconeixement de Bloch, i fins i tot una crida d'exigència (i una implícita crítica) a totes les altres maneres habituals de fer història de la filosofia: unes maneres molt més ortodoxes, molt menys parcials i partidistes que la manera blochiana, però tampoc del tot correctes és a dir, ortodoxes-ni del tot lliures de parcialitat; $i$, per això mateix, unes maneres també partidistes. Cal criticar, doncs, Bloch pel fet que, del desenvolupament històric del filosofar, només en tracta $i$ aprofita uns moments i uns aspectes determinats; però en això mateix té el mèrit de descobrir-hi, en tals moments $i$ aspectes (que resten com si estiguessin oblidats en un racó pels altres historiadors de la filosofia), allò que sols una ment lúcida - filosòficament desperta, creadora- és capaç de descobrir.

3. Quant als pensadors que tracta, l'exposicí́ blochiana de la història de la filosofia medieval és prou completa, com ja hem apuntat ${ }^{20}$. No és, doncs, la selecció d'autors allo que serà objecte de la nostra crítica, sinó que ho serà el tractament que en fa Bloch.

Una premonició del tarannà d'aital tractament es troba ja en la «Introducción al volum; un tarannà que ens permet de veure el que de límit i, alhora, de grandesa té Bloch. Aquest, en efecte, ens hi presenta un doble tret com a comú i general en tot sorgiment d'un autèntic filosofar: l'efectiu reconeixement social del treball $\mathrm{i}$ la no vigència social - almenys en la pràctica - dels estaments sacerdotals. Explícitament, això ho diu pel que fa a l'origen de la filosofia a Grècia ${ }^{21}$, com també ho havia explicitat ja en una altra ocasió, en relació amb el gran «pre-renaixament» que s'esdevé a l'Islam ${ }^{22}$; anticipació, aquest, d'aquell altre Renaixement - l'europeu-

20 Vegeu supra n. 18.

21 Vegeu BLOCH, $Z W 13$ y s.; «Com he dit, el pensar brolla del treball. Aquest brollador restà sens dubte prou obstaculitzat quan començà la filosofia grega: $i$ això pel fet que el treball ha estat menyspreat en totes les societats esclavistes i feudals. [...] El desenvolupament del comerç, el triomfant capital mercantil, produïren - primer en les colonies gregues, després també en la metròpoli- tot un salt en la més propera suprastruetura, és a dir, en les relacions polítiques $i$ jurídiques. [...] En les colònies gregues songi per primera vegada la filosofia; no fou en la metròpoli, a Atenes. Aquif, hi arribà molt més tard, com importada per Anaxàgores đe Klazomene (Àsia Menor). En aquestes colònies hi havia solament comerciants, artesans, esclaus; els temps de la reialesa i del feudalisme feia, dones, ja molt que se n' havien anat. En altres mots : la filosofia grega es formà en una societat comercial afermada. Heus aquí un primer factor: l'altre rau en l'absència d'una casta sacerdotal com a institució de tipus alhora feudal i clerical.s (subratllat nostre).

22 Vegeu BıосH, Das Materialismusproblem, seine Geschichte und Substanz, ed. cit. p. 481-484: «Ibn Sina era metge: mai no ha estat monjo. Tampoc no ho van ser els altres 
per al qual tornarà a establir com a vigent el mateix doble criteri ${ }^{23}$. I com que aital postulat val també per a l'Edat Mitjana, la valoració global que del

pensadors islàmics importants, que vivien mundanament i pensaven en termes cientifico-naturals. Sí, tota la societat islàmica, malgrat les seves formes feudals i malgrat el seu ardor bèl-lic espiritual, es regia segons una llei diferent de la llei medieval curopea. Al seu propi aire, era una primerenca societat burgesa, amb un ordre residual de tribus; en ella, tanmateix, hi dominava el capital mercantil, el qual li donava l'impuls essencial. La Meca, indret d'origen de I'Islam, era un antic gran centre comercial. [...] Pocs anys després de la mort de Mahoma el califa Omar habilità la rada de Basra, amb la qual cosa féu entrar tota la navegació del golf Pèrsic sota l'influx àrab. Hom pot, doncs, afirmar cum grano salis : la societat àrab tingué amb cinc-cents anys d'anticipació les seves Venècies i els seus Milans [...] Aixf, tot altrament que la primera edat mitjana europea, la dels arabs es basava en comerciants cosmopolites, en una florent producció de mercaderies i en una esplèndida circulació d'aquestes, en comptes de basar-se en zones mig-selvatiques $i$ castells, en petites viles $i$ convents. [...] Bujara, la ciutat prop de la qual havia nascut Avicenna i que queia sota jurisdicció de Bagdad, pertanyia a l'àmbit cultural jorrémico-iranià, i la mateixa Bagdad [...] floria com a seu de la civilització més avançada d'aquell temps $i$, ensems, d'una prevalença de la cultura mundana enfront de l'ortodoxia, enemiga de la raó. El tarannà liberal que s' hi originà [...] explica i envolta el que fou peculiaritat dels pensadors islamies més importants: la de ser metges, no monjos: naturalistes, no teòlegs. [...] És, dones, palès que la situació $i$, per tant, la manera no clerical de pensar pròpies dels grans metges-filòsofs de l'edat mitjana islàmica es configuren ben altrament que les de l'Europa feudal i clerical.n (Hi ha trad. cast. del passatge, a Avicena y la izquierda - aristotélica, ed. cit., p. 13-16). A propòsit de la citacio, i en relacio amb el tema apuntat en la n.19, val a dir que la lectura blochiana de l'Islam medieval no deixa de ser prou upartidistas, també en l'esmentat sentit pejoratiu del terme (ho diem això sobretot respecte al conjunt de l'aportació blochiana sobre al' esquerra aristotèlicas).

${ }^{23}$ Vegeu BLOCH, ZW 175 i s. (149 i s.): eL'activitat és la nova consigna. L'home nou treballa, ja no se n'avergonyeix. L'interdicte que la noblesa havia llançat sobre el treball, considerat com a degradant i deshonrós, és aixecat; hom assisteix al naixement de l'homo faber que, sense tenir consciència del canvi esdevingut, transforma el món amb la seva activitat. L'economia dels inicis del capitalisme s' imposa resoludament, la burgesia ciutadana, aliada a la reialesa que s'encamina cap a l'absolutisme, cerca de derruir el feudalisme cavalleresc. És la victoria d' esforços que, a Itàlia, s' havien traduit, el segle xII i sobretot el xav, en revoltes d'artesans. Com a factor sens dubte primordial, el capital comercial adopta una actitud més emprenedora. Els Mèdici funden a Florència la primera banca. L... I L'economia de mercat de l'inici del capitalismes'obre, doncs, pas; i fou a Italia on les traves econòmiques de l'època feudal havien estat allunyades per primera vegada. Per això és a Itàlia on ha començat el Renaixement. Hi ha, breument, dos fets nous: la consciència de l'individu, tal com s'ha desenvolupat a partir de l'economia capitalista individual enfront del mercat tancat de les corporacions, d’una banda, i la impressió d'immensitat que ha substituỉ la imatge del món artificial i tancada de la societat feudal $\mathrm{i}$ teològica, d'altra banda* (subratllats nostres). No ha estat, tanmateix, per remancar l'esmentat «doble criteri» —el d'un reconeixement social del treball i el de la no vigència social de cap casta sacerdotal - (doble criteri obviament present en el text) que hem fet aquests subratllats, sinó que els hem fets per destacar les correccions que ha calgut fer a la trad. cat. que en principi seguim: BLосH, La filosofia del Renaixement, Edicions 62, Barcelona 1982, 190 p; aquesta traducció fou feta sobre la versió francesa de l'edició no definitiva del text blochià aparegut com a Vorlesungen zur Philosophie der Renaissance (Suhrkamp, Taschenbuch 75, Frankfurt del Main 1972), però corregit per a ser inclòs en Intermons en la historia de la filosofia (vegeu ZW 173-302 [147-257]), i és força criticable (a diferència, per exemple, de la traducció castellana, del mateix any, de l'esmen- 
pensament medieval fa d'entrada Bloch serà ben peculiar: com a filosofia, només val en tant que assumpció del pensament grec ${ }^{24}$. Ara bé, és cert, i cal subratllar-ho, que hi ha relació directa entre reconeixement del treball $\mathrm{i}$ inicis del pensament ${ }^{25}$, igual que hi ha relació inversa entre domini de casta i llibertat de pensar ${ }^{26}$; però és més que qüestionable d'atribuir massa esquemàticament (i exclusivament) aquell reconeixement $i$ aquest domini a una $o$ altra èpoques històriques segons que llurs productes especulatius ens siguin més o menys simpàtics o bé ens semblin molt o poc aprofitables ${ }^{27}$.

tat Subjecte-objecte; vegeu J.M. UdiNA, «Al voltant de Hegel. Ernst Bloch ben traduĭ al castellàs, dins Enrahonar, 1984, n. 7/8, p. 168s. i 171). A part d'això -i un cop més seguint el tema apuntat en la n. 19-, val també a dir que, globalment considerada (i no sols, ni més precisament, pel contingut de I'anterior citació), la interpretació blochiana dels pensadors renaixentistes és certament epartidistan en el sentit pejoratiu del terme; a l'assumpte, vam dedicar-li tot un ampli estudi en la nostra tesi doctoral (vegeu J.M. Udina, La constitucion utópica de lo humano. Emst Bloch: filosofía de la esperanza y crítica filosófica, Univ. de Barcelona, Fac, de Filosofia i Ciències de I'Educació, Barcelona 1976, vol. II, p. 332-358.

24 Vegeu BLOCH, ZW 14 [13]: aLa filosofia grega es formà en una societat comercial afermada. Heus aquí un primer factor; I'altre rau en l'absència d'una casta sacerdotal com a institucio de tipus alhora feudal i clerical. L'esfondrament del domini sacerdotal havia esta naturalment preparat per la barreja dels darrers temps feudals amb els interessos mercantils i amb una corresponent individualització en els estaments dominants; amb aixo, de l'antiga casta sacerdotal només perduraven els anomenats profetes, perঠ̀ mancats també de tota organització i de tot poder mítico-clerical. I molt més endavant, en l'Edat Mitjana - d'estrucrura certament feudal i clerical-, hom ja no podia, tanmateix, imvalidar aquella filosofia, emancipadora dels costums $\mathrm{i}$ del pur sofriment mitic. Fermament nodrida d'antigues fonts, aparegué com a escolàstica $i$, en qualsevol cas, esdevingué serventa no d'un mite insuficientment racionalitzat, sinó de la teologia més Aristòtil. També així perdura vivent un impuls vers la II-lustració, en el sentit de la definició kantiana que la Il-lustració és la sortida de l'home d'una minoritat mantinguda per pròpia culpa.n (subratllats nostres).

$25 \mathrm{Si}$ més no, recordem quant a això el famós cap. IV de la Fenomenologia de l'esperit de HEGEL.

26 Pensem, sense sortir del nostre segle, en qualsevol despotisme o totalitarisme: en el règim franquista, entre nosaltres, en els imperis hitlerià o stalinista (marxista-leninista), o en tants d'altres episodis d'època prou recent massa sovintejats pertot arreu.

${ }^{27}$ Bloch matcix havia de fer molts equilibris a I'hora de presentar-nos el naixement de la filosofia a Grècia, on — segons reconeix - valia «el fet que el treball és quelcom menyspreablew (ZW 14 [13]; vegeu supra, n. 21); d'altra banda, reduïa també la presència de la casta sacerdotal grega a enomés [...] els anomenats profetesn (vegeu n. 24, ZW 14 [13]; subratllat nostre), afirmació històricament més que discutible... En qualsevol cas (i per oferir només un segon exemple de la quiestionabilitat del discurs blochia quant a això), és sens dubte l'entusiasme - d'altra banda, d'arrel també marxista - de Bloch per pensadors islamics com Avicenna i sobretot Averrois allo que determina en bona part l'interès del nostre autor a subratllar una diferència qualitativa - pel que fa al progrés econòmico-mercantil (és a dir: a una positiva valoració social del treball) i a l'influx que una casta sacerdotal té en la societat-entre el món de l'Islam i l'Europa també medieval de la mateixa època. Però, sense entrar a discutir l'exactitud històcica de caracteritzacions del món àrab com la d' una societat renaixentista amb cinc-cents anys d'anticipació (vegeu, n. 22), hom no pot deixar de constatar que el upensament» de l'islamisme medieval no es deixa reduir a només el d'A vicenna o Averrois, sinó que 
Pel que fa als tres autors situats a cavall de l'època antiga i la medieval - Tertul-lià, Orígenes i Agustí d'Hipona-, també en llur tractament ens mereix Bloch, alhora que un reconeixement d'encert, una inevitable malfiança. L'autor, en efecte, és capaç de comprendre i subratllar l'esforç de racionalitat que hom pot discernir en el credo quia absurdum mateix d'un Tertul-lia ${ }^{28}$; però ja no és capaç d'entusiasmar-se amb la corresponent línia cosmovisional (que, en canvi, un kierkegaardià o un nietzscheà celebrarien prou!) - $\mathrm{i}$ acabarà ridiculitzant-la amb l'exemple d'una paradoxa ben poc gloriosa $^{29}$ - mentre que sí que s'entusiasmarà amb un Tertul-lià que li sembla anticipar l'esquerra aristotèlica que culmina (parlant blochianament) en l'Islam ${ }^{30}$. ¿No serà que l'extrapolació que això comporta és sols l'altra cara de la manca d'agudesa amb què Bloch cerca d'interpretar l'atribució que de la corporalitat fa Tertul-lià a Déu ? $^{31}$ ¿I no és una equivalent manca d'agudesa el que fa que Bloch tampoc no encerti a relacionar la creatio a nihilo - la qual ell s'estimaria molt més que fóra ex nihilo - amb el credo quia absurdum ja esmentat? ${ }^{32}$ ¿És l'entusiasme per un contingut

ho és també el d'una complexa multitud d'altres figures de respeculació: i totes elles -Avicenna mateix en un lloc no secundari! - tenen I'Alcorà i la corresponent fe musulmana com a principi i referència fonamental de llur pensament. En fi, tot i acceptant que l'Islam no té una estructura d'església com — per exemple- la del cristianisme, resta difícil d'admetre que no inclogui cap casta sacerdotal, o equivalent, amb un domini social efectiu.

28 Vegeu $Z W 36$ y 5 [33]: EEl seu principi fonamental diu així: credo quia absurdum; i sembla d'entrada quelcom ben minsament filosofic. Tanmateix, en ell no ha estat suprimida la tasca de filosofar, en la mesura que horn hí estabieix exactament un concepte - com és ara el de l'absurd-. I precisament com a coneepte afirmat de manera reflexa en lloc d'una fe merament passiva. És per això que hi ha també aquí un pensar propi de la ll-lustració, almenys com a pensar que vol entendre la fe justament com un pensament en tot cas ben cert de si mateix, $\$$

29 Vegeu ZW 37 [33]; - El cristianisme, que és absolutament paradoxal, exigeix el capgirament de les motivacions en l'home: "Estimeu els vostres enemics", "si algu et bufeteja la galta dreta, para-li també l'altra" [I'autor al-ludeix Mt. $5: 44$ i 39, respectivament]. El paradoxal arribà a extremar-se de tal manera que, encara en el s.xIX, hi ha hagut sectes noruegues que proclamaven que l'infern era el paradís dels cristians: els cristians més pietosos anirien a l'infern, i els altres, al cel, atès que per al cristià no hi ha cap ventura, sinó només sofriment, sofriment, sofriment; aquest sofriment i el turment de l'infern són, doncs, la felicitat dels cristians, $n$

30 Vegeu ZW 38 [34]: - Tenim, doncs, allà dalt del cel un tros de matèria intel-ligible, relacionada amb la hyle noeté, aquella matèria pensant, espiritual, que segons Plotí es troba en Déu. Això és anunciat amb anticipació per Tertul lià, amb la qual cosa hom introdueix a través de la sensibilitat un tros de materialisme en les altures. D'aquesta manera Tertul-lia és justament una peça intermediària d'unió dins l'esquerra aristotèlica. s

31 Vegeu ZW 38s [34]; «No sols és que la matèria sigui, per així dir-ho, ennoblida, sinó que rep la maxima dignitat teológica; no sols és que la matèria esdevingui part integrant de Déu, sinó que Déu esdevé moment de la matèria. [...Tertul-lia] en fa, de Déu, una matèria.»

32 Vegeu $2 W 39$ y s. [34 s.]. Bloch redueix aquf l'origen historic del teologumen de la 
doctrinal allò que impedeix Bloch d'entendre aquest en profunditat, profunditat que si assoleix l'autor en referir-se a continguts envers els quals es manté desapassionat? Car igualment meritori és el fervor blochià envers la transcendència històrico-revolucionària de l'accentuació creient de la figura de l'Esperit, i això no sols amb relació a Tertul-lià, sinó també respecte a Orígenes $^{33} ;$ cal, però, qüestionar-se alhora si no fóra millor posar menys fervor $i$ fer un discurs més assenyat, històricament $i$ hermenèutica més just i valuós ${ }^{34} .1$, inversament: $\iota$ és clau de l'aguda interpretació que fa Bloch de l'il-luminisme augustinià - com a pregunta per l'aspecte objectiu. fins aleshores poc atès, del coneixement ${ }^{35}$ - el fet que no estigui ni de lluny entusiasmat pel sentit $\mathrm{i}$ el contingut concrets (de caire inquiestionablement teocèntric i creient) que aital doctrina té en Agusti? ${ }^{36}$; i quant a la resta de

creació als mites egipcio-babilònics (la relació amb els quals, quant a l'expressió del teologumen, ningú no nega), i de cap manera no el vincula a allò que és el fet originari - històricament parlant- de la fe i del credo israelítics: l'alliberament de l'esclavatge a Egipte i l'exode subsegüent. Atès tanmateix que alliberament i èxode sơn inseparables, l'étade és també factor genèric del mateix teologumen israelítico-cristià de la creació; en canvi, si alguna cosa tipifica la interpretació blochiana del missatge biblico-cristià, és la més radical contraposició entre el Déu de la ereació i dels orígens (és a dir, Déu com a hipòstasi) i el Déu de l'èxode i de l'esperança, de l'eencara-non i del futur utòpico-escatològic (és a dir, d'allò que pot exdevenir-se com a Ultimum, com a Summum - en alemany, das Ueberhaupt- i com a Utopicam). Quant a això, vegeu E. BLocH, Atheismus im Christentutn, Suhrkamp, GA 14, Frankfurt del Main 1968, 364 p. (trad. cast. El Ateismo en el cristianismo, Taurus, Ensayistas, 234, M. 1983. 270 p.).

33 Vegeu $Z W$ 40-42 [35-37] i $42 \mathrm{~s}$ [37 y s.], respectivament, en relacio amb uns evangelis mai no acabats (i que impedeixen fer de la veritat quelcom absolut) i a un tercer Testament. inspirador dels moviments revolucionaris medievals (quant a això, vegeu Thomas Mïntzer. teóleg de la revolució, citat en la n.4).

34 Vegeu, a tall d'exemples: «Paràclit, Paraklétos, no significa originàriament en grec àtic res més que assistent davant els tribunals, advocat; bé que Luter ho tradueix per "consolador", la qual cosa atorga al passatge [...] tot un aire de rectoria, de casa de pastor protestants ( $Z W 40$ [36]: hom haurà de preguntar-se, tanmateix, si no fóra ef gree de fa koiné - i no l'atic- allo que filologicament hauria de confrontar-se aqui): «En el passatge biblic citat [el de Jn. 15: 26] hi ha encara quelcom més: Jesús hi diu [...]: "Jo us l'enviaré [el Paràclit], jo; no serà el Pare qui us l'enviarà; $i$ ell donarà testimoni de mi". Hom veu en la separació entre Pare i Fill allo que hi ha de marcionisme en un evangeli d'un Déu totalment nou. Això és quelcom de rebel $\mathrm{i}$ perillós, és ua apostar per l'huma en contra del divi; $Y$ 'home és millor que els seus désin (ZW 40 y s. [36]: com a model d'exegesi - sempre igualment radical i que es perllonga encara molt més enlla-. és facil de veure la seva fragilitat!): $i$ wel que de nou hi ha a Joaquim [de Fiore] és el fet que, del que era filologia, en féu filosofia de la història: car la triple lectura [del sentit] de I'Escriptura que van fer Origenes era filologias (ZW 43 [38]; millor, potser, de no fer pas cap comentari!).

35 ZW 46 [41].

36 Vegeu lbid., segons Bloch, la pregunta «com ha d'estar constituit l'objete perquè esdevingui cognoscibles, Agusti la respon: *només mitologicament, mitjançant una font de coneixement del tot transcendents. 
l'exposició blochiana sobre aquest - pessimista idea del temps, en les Confessions, i optimista idea de la historia, en De civitate $\mathrm{Dei}^{37}$ - I'anàlisi i el judici respectius desbordarien els límits del present article, car l'aportací́ de Bloch quant a això remet a la seva comprensió global del missatge bíblico-cristià, típicament palesada en el volum Ateisme en el cristianis$m e^{38}$.

Desbordaria també els límits d'aquestes pàgines el fet d'intentar analitzar, ni que fos mínimament, el tractament blochià de tots i cadascun dels autors pròpiament medievals. Per això, ens centrarem sobretot en un de sol: en concret, Anselm de Canterbury ${ }^{39}$. Bloch el presenta a partir d'una doble contraposició; d'una banda, amb Roscel-lí (i el nominalisme), pel realisme platònic d'Anselm - aspecte que tampoc no suscita l'entusiasme de Bloch- ${ }^{40}$; d'altra banda, la contraposició entre el credo quia absurdum de Tertul lià i el credo ut intelligam anselmià — aspecte, aquest, que sí desperta en Bloch un cert fervor- - I és que aquest tema que l'autor no pot eludir el tractament de l'anomenat (des de Kant) argument ontològic de l'existència de Déu; una qüestió inexcusable en parlar d'Anselm, però per la qual Bloch mai no podrà sentir cap il.lusi $6^{42}$.

\section{Vegeu ZW 47-51 [41-44]}

38 Vegeu n. 32.

${ }^{39} \mathrm{~L}$ 'hem escollit per l'interès que Anselm sempre ens ha merescut: vegeu J.M. Udina, «Fe i rao: un problema no tan anticn. (Enrahonar núm. 4, 1982, p. 71-80), on retrobàvem la quiestió que l'argument anselmià planteja en un àmbit més específicament filosòfic, i on crèiem poder discernir sempre pertot ( $\mathrm{i}$ en relació amb Bloch mateix també!) una resposta equivalent a la d'Anselm.

40 Vegeu $Z W 70$ [60]. De Roscel-If (del qual ha tractat en el capitol anterior: $Z W 68-70$ [58s]), Bloch en rebutja el nominalisme, que jutja extremat i purament sensualista (i que fa del seu portaveu un Mach de I alsa edat mifiana: ZW 69 [58 y s.]): però l' autor rebutja igualment l'extrem oposat, el realisme platònic d'Anselm: $\alpha$ Amb el refús dels conceptes universals /pel nominalisme roseel-lia] s'aguditza l'esguard vers l'individual sensible: un esguard apropiat per a apartar-se del celestial $i$ dirigir-se a l'ençà d'aquest món, i al qual s'enfrontà amb un decidit realisme conceptual Anselm [...], el qual seguia en això un mandat clarament social de l'Església.» (ZW 70 [60]). En canvi veurà en Abelard el just punt mitjà: aQuant a la teoria del coneixement, a la quiestiò dels universals, la doctrina d'A Abelard es troba entre el nominalisme i el realisme* (ZW 79 [68]).

${ }^{41}$ Vegeu ZW 70 y s. [60], quant a la contraposició d'ambdós. Quant al fevor blochià - no exempt d'apassionada extrapolació - per la consigna d'Anselm, vegeu ZW 56 [48]: aNo obstant el mandat expressament apologètic [que el saber havia de sotmetre's a la fe], s'afermà de tant en tant i en força mesura - a partir del saber mateix - la certesa que, inversament, era la fe la que havia de sotmetre's al saber; $i$ aixo és aquí [en relació amb Tertul-lià] l'important. Així, pogué transformar-se finalment el credo quia absurdum en el credo ut intelligam d'Anselm de Canterbury, com a renovada exigència de la filosofia en contra del seu fer de serventa de la teocràcia.s

${ }^{42}$ Bloch tracta el tema perquè no té més remei, perquè no pot deixar de fer-ho: si no en parlava, fóra millor que no hagués abordat Anselm. De Tomàs d'Aquino, Bloch podrà tanmateix recollir diversos temes, i dissimufarà amb això el fet que deixi de banda temes com el de les cinc vies de l'existència de Déu o, afi a aquestes, el de l'analogia entis; i no en tracta, 
No és estrany, doncs, que una breu exposició del famós argument vagi seguida d'una àmplia crítica d'aquest, en la més pura línia kantiana ${ }^{43}$; per bé que tampoc no hi manca - quant a la manera de dir- l'aportació personal típicament blochiana ${ }^{44}$. I encara que una tal crítica sigui presentada com a crítica externa - d'altra banda, prou fàcil i que està a l'abast ${ }^{45}$ Bloch no la farà seguir de cap altra d' cinterna» (tal volta, aleshores, no tan crítica), com si l'argument no li semblés mereixedor d'un esforç ulterior de comprensió «des de dins», que potser corregís la crítica «externa» feta ${ }^{46}$. A més, si quelcom hi ha per a Bloch digne de lloança en l'aportació anselmia-

malgrat que sí que aborda el tema de la doctrina tomàsica de la individuació per la matèria i de la diversitat entre formes inherents i separades (vegeu ZW 94-100 [81-85], tema no deslligat del de Déu i les vies que duen a EII) o el tema de la teoria del coneixement (vegeu ZW 88-94 [76-81], tema igualment vinculat al d'aitals vies $i$ al de la corresponent analogia del coneixement relatiu al divi). Amb aquesta seleceió de temes, l'aportació de Bloch sobre l'Aquinat és prou més reeixida que no pas la feta sobre Anselm; i fins i tot té moments de notable serenitat en la valoració (com és el cas de l'exposició sobre psicologia, ètica i filosofia social tomistes: vegeu $Z W$ 100-103 [85-88]). No fa bé certament l'autor en no tractar ni les cinc vies ni l'analogia en l'obra de Tomàs d'Aquino, però en no tractar-les fa quelcom millor que no si les hagués tractades com ho ha fet amb el tema de l'anselmià. I és que, aquest, sols l'ha tractat perquè no ho ha pogut evitar: sense sentir cap il-lusió, sinó ben al contrari.

${ }_{43}$ Bloch exposa primer àmpliament la crítica que de l'argument ja féu Gauniló (precursor extrinsec de Kant: ZW 72 [61]), i centra després la seva refutació d'Anselm a partir de la distinció de Kant (crític conscient $i$ radical, en la Crítica de la rá́ pura, de l'argument ontològie: ibfd.) entre predicats i existència, i addueix expressament l'exemple kantià dels cent tàlers (vegeu $Z W 72-74$ [62] i, també, 75 [64]).

44 Vegeu, si més no, la «versiós blochiana de la cèlebre objeceió de Gauniló d'una illa perduda (mai no trobada per ningớ, de tan perfecta!): «Atès que la societat sense classes és la més perfecta de totes les societats que hom pugui pensar, cal consegüentment que existeixi: car, si no existís, ja no fóra la societat més perfecta. Primer, però, cal fer camf vers ella. Hi ha un factor subjectiu $i$ hi ha també el coneixement del factor objectiu; hi ha l'aprofitar les bones possibilitats i l' evitar-ne les dolentes, i així successivament; i no obstant això, la realització de la societat perfecta segueix estant encara en perill [...]. La societat perfecta és, doncs, cosa ben complicada, i de cap manera no queda establerta amb el seu conceptes (ZW 74 [63]); i poc abans s'ha dit: «El record de Gauniló d'una illa perfecta és - sigui dit de passada - una reminiscència prou interessant: és l'únic testimoni que en el s. xı les utopies no havien estat certament del tot oblidades. $\gg(Z W 72[62])$.

45 $Z W 71$ y s. [61].

46 No sols com a externa, sinб també per altres motius és injusta la crítica blochiana de ranselmià: 1) Bloch oblida que Anselm mateix va refutar —en la seva Apologia contra Gauniló-l'esmentada objecció d'aquest de l'illa perduda perfectíssima (vegeu $2 W 72$ [62]). 2) En distingir l'existència $\mathrm{i}$ els predicats, Bloch descriu la primera com a ésser intensiu i woluntariós, i adhuc com a quelcom ni tan sols logic, en sentit estricte, però tot seguit remarca (sorprenentment) : $*$ El que acabo de dir no és certament del tot valid, però és que exagero per a fer la critica [d'Anselm]; és per això que he d'establir una separació [entre existència i predicats] ben gran, una separació dualistos (ZW 73 [62]); però fer crítica a base d'exageracions no sembla que sigui ni honest ni seriós. 3) Com a confirmació de l'exagerada ruptura entre existència i propietats, Bloch invoca Aristòtil i la seva distinció entre hoti i diofi, entre el quod (el Dass alemany: en catala, wel fet quew) i el quid (el Wass: wel quès): és a dir, entre 
na, únicament serà herència de Plató (el plantejament, en concret, del problema de la gradació de l'ésser $)^{47}$; com a específica aportació pròpia d'Anselm, Bloch no sembla, doncs, poder trobar-hi res ${ }^{48}$. I quant al mateix argument anselmià, l'autor tan sols sabrà sentenciar: «Pel que fa a la prova d'un Déu omnipotent, summament bo i omniscient, hom només pot dir, davant la misèria de la historia universal $\mathrm{i}$ davant aquesta desgràcia que anomenem societat de classes: vet aquí l'aspecte d'una tal hiposstasi [divina]. La qual cosa, hom pot també formular-la més filosòficament en termes d'un enciclopedista francès: I'única teodicea que hom pot sostenir de Déu i del seu ésser és que Déu senzillament no existeixi ${ }^{49}$.

La darrera paraula que Bloch té per a l'anselmià no és, doncs, sinó la del més tòpic lloc comú de les més típiques argumentacions ateístiques; i recorrer a un tal lloc és fins i tot el que més filosóficament creu poder fer! $!^{\text {so }}$ I és que Déu, com a hipòstasi —envers la qual cerqui el creient qualsevol prova o via d'accés-, mai no podia Bloch acceptar-lo, ni tan sols com a simple hipòtesi (com a pura possibilitat, més enlla del fet que hom no vulgui o no pugui admetre'l ni com a probable) ${ }^{51}$. Aleshores, però, ¿és factible, és lícit de pretendre apropar-se a un pensament tan centrat en la hipòtesi i en la hipòstasi Déu com el medieval? ¿És versemblant de pensar que hom pugui comprendre aquest pensament mínimament des de dins,

I'existència o facticitat i I'essència o idealitat (vegeu ZW 73 y s. [62 s.]); I'autoritat aristotèlica és tanmateix prou qüestionable aquí (els grecs mai no distingiren entre essència i existència!), com també ho és la referència al Dassi al Wass (difícilment homologables, tant en grec o llatí, com en catala). 4) En fi, pel que fa a l'exposició mateixa que - a manera de resum- ofereix Bloch de l'argument d'Anselm, no és encertat l'ús d'expressions com ens perfectissimum, o ens realissimum (vegeu $Z W 71,72$ i 76 [61, 62 i 65]) el significat actual de les quals és tan sols obra d'una escolàstica molt posterior a Anselm i la literalitat de les quals no solament no es troba enlloc en el text de l'argument (Prosiogion, 2-4), sinó que fins i tot Anselm mateix refusà, en considerar-les formulacions incorrectes (vegeu Apologia contra Gaunilo, 5).

${ }^{47} \mathrm{ZW} 76$ [64].

48 Vegeu $Z W 76$ [64s]: «Anselm ha assenyalat un problema important en la gradació de Yésser per ell introdừda, en ocasió de la seva prova [... ], amb la categoria del realissimum en paral-lel amb la del perfectissimum. No ha brollat [aquest problema] del terra mateix d'Anselm, car, com tota la filosofia medieval, deriva de premisses gregues; en aquest cas, del darrer Plató, sobretot: però Anselm I' ha desenvolupat fonamentalment. "

${ }^{49} \mathrm{ZW} 76[65]$.

50 A la seva anterior crítica externa de l'argument. Bloch es limita a afegir una última crítica no menys extrinseca (no sols es mou en l'àmbit del problema moral de l'existència del mal en el món, sinó que - altre cop-és pura repetició del que altri ha dit); Anselm la coneixia sens dubte, i no creia que afectés la prova. Tomàs d'Aquino recull I'objecció precisament abans d'iniciar les seves cine vies, i la resol tot seguit (vegeu $S T$ I q.2 a.3, ad I).

${ }^{51}$ Aquí es troba la clau de volta de tot l'edifici diguem-ne ereligiosos-filosofie de Bloch: cal negar el Déu de l'origen, el Déu-hipòstasi (vegeu n. 32) pel mateix i amb la mateixa força que cal deixar obert l'espai que ocupava el Déu de l'exode, de l'encara-no i del possible futur utopic... 
com per connaturalitat i adequadament? En qualsevol cas, la hipòtesi Déu - com a hipòstasi (és a dir, com a quelcom ja existent, i no com a pur «espai buit» d'un futur utòpic) - s'identifica per Bloch amb aquella altra hipòtesi de principi: la d'una «casta sacerdotal» com a factor que impossibilita l'autèntic filosofar, en impedir la llibertat de pensar. Com a tal, el pensament sobre Déu — com també el pensament asacerdotalment» determinat-, Bloch mai no se'l podrà prendre seriosament. Es tracta, en aquest punt concret, d'un límit de Bloch - i del seu fer història de la filosofiaque, excepcionalment, no denota alhora en ell cap grandesa.

4. No volem, però, concloure negativament. Fer-ho fóra injust amb Bloch i amb el seu fer historia de la filosofia, tasca en la qual tan sovint ha encertat de fer, precisament, allò que trobem a faltar en el seu tractament d'Anselm: una comprensió des de dins que faci possible anar més enllà de la pura crítica «externa» de l'assumpte ${ }^{52}$; en relació amb Tertul-lià i Agustí, hem parlat de casos en què ho feia, i en podríem multiplicar els exemples ${ }^{53}$. Per això serà més justa cloenda d'aquestes pàgines oferir una darrera perspectiva general sobre el tractament blochià de la resta d'autors medievals i, alhora, una valoració final positiva (malgrat les crítiques fetes en punts concrets) de l'aportací històrico-filosòfica i filosòfico-històrica de Bloch.

Aquest mateix ens brinda la perspectiva general, a l'inici de l'últim dels seus capítols medievals, relatiu a Nicolau de Cusa: $\propto$ L'època en què aquest va viure es va situant com entre dues llums: com més va més s'apropa a l'aurora de la modernitat; i, quant a l'Edat Mitjana, resta ja de fet com en la nit. Allo, però, de l'obscurantisme de l'Edat Mitjana - adhuc en la seva esplendor - fou un engany, que tingué durant la Revolució francesa un significat polític progressista, en contra del reaccionarisme catolic. I tampoc no fou un invent dels historiadors, sinó d'aquells qui necessitaven una palanca contra la noblesa i el clergat. Fou així que hom menyspreà fins i tot l'art medieval i liquidà el gòtic com a ornament monacal el més dolent. Aquesta infravaloració de l'art medieval ha esdevingut actualment insostenible; en canvi, en una mena de curiosa doble comptabilitat, la infravalora-

52 Models d'intent de comprensió interna (i així, si alhora és crítica, portadora d'una crítica interna, i no simplement externa) serien les obres tant de K. BARTH (Fides quaerens intellectum. Anselm Beweis des Existenz Gottes, Kaiser, München 1931 (trad, franc. : Delachaux-Niestlé, Nauchatel i París 1958), i d'E. Gulson, «Sens et nature de l'argument de st. Anselms, dins Archives d'Histoire Doctrinate et Litteraire du Moyen Age, 9, 1934, p. 5-51). L'article gilsonia defensava el valor filosofic de l'anselmià i responia no sols al llibre de Barth -que reduìa l' argument a leologia -, sinó també a un altre article, d'A. Stolz: *Zur Theologie Anselms im Proslogions, dins Catholica, 1933, p. 1-24) i que interpretava l'obra d'Anselm com a mistica.

${ }^{5} \mathrm{El}$ volum hegelià de Bloch, Subjecte-objecte - ja esmentat en la n. 2-, en fóra l'exemple més típic i alhora més ampli. 
ció de l'escolàstica encara perdura en bona part. Si hi hagué aquell art, cal que ens preguntem: $i c o m$ és, aleshores, que només hi havia una ciència tan miserable? Si decididament l'ideologic representa un moviment coherent. no podem ja separar radicalment art $i$ ciència ${ }^{54}$. Per a Bloch no hi ha cap fonament històric seriós per parlar d'obscurantisme medieval i de tòpics similars; amb un bon argument de coherència equipara la grandesa del pensament escolàstic a la de l'art medieval, aquesta última per ningú no quiestionada avui.

Una tal equiparació, ja l'ha feta pàgines enrera - precisament en el primer dels seus capítols medievals-, en referir-se a les summes $i$ altres construccions medievals del pensament oral - docent-o escrit ${ }^{5}$. Fins a tal punt considera valuós el mètode inquisitiu de la disputatio medieval, per exemple, que no dubta d'aplicar-lo a una queestió tan actual com la de l'atzar, per tal d'oferir-ne la corresponent solució amb tota riquesa de matisos ${ }^{5}$. Clou així l'esplèndida digressió (amb una frase que evoca gairebé literalment una cèlebre dita de Lenin sobre l'idealisme): «Hom no pot exigir de l'escolàstica que coincideixi amb la dialèctica materialista; aquesta es troba, tanmateix - pel que fa al mètode-, més a prop d'aquella que no pas de l'empirisme, sempre massa simplista ${ }^{57}$, . Quan, a més de la riquesa del mètode, Bloch detecti una aportació doctrinal o una actitud personal concretes en què pugui o cregui poder veure anticipació de futur, transcendència sobre la pròpia època o, breument, signes de qualsevol vers endavant utòpico-progressista, aleshores la interpretació que en faci serà d'una inapreciable riquesa de suggeriments. En fóra exemple prototípic tot el capítol dedicat a Abelard, des de la seva primera caracterització com «un dels pensadors de més gran vivesa en els inicis de la darrera Edat Mitjanas ${ }^{58}$, fins a la seva presentació final com a autor de «doctrines insolites, la tensió de les quals envers llur entorn no podem senzillament mesurar avui ${ }^{59}$; $\mathrm{i}$ tot remarcant la seva central tipificació com a autèntic creador medieval (en això, tal volta, extramedieval?) d'un pur ús de la raó: «Allo era dialèctica teològica, capaç de fonamentar teològicament, ni

54 ZW 163 [139].

55 Vegeu $Z W 62$ [52 y s.]: «Menció a part mereix aquella impulsiva força epocal que lligà de forma tan cridanera les construccions del pensament il'arquitectura. La subtil profunditat, les diverses formes de conjunció $i$ el sublim impuls de centralitat de les summes escolàstiques, ¿no tornen com a aparèixer en l'articulació tan subtil, en l'ornamentació de tan esplèndid moviment $i$ en is mosumentalitat tan sublim de les catedrals gotiques, com es el cas, particularment, de la d'Estrasburg?\%.

56 Vegen $2 W 62$ s. [53].

57 ZW 63 [53]. La frase de Lenin amb la qual aquí es juga diu aixi: aL'idealisme lúcid resta més a prop del materialisme lácid que el materialisme estúpid.

$58 Z W 76[66]$.

59 ZW $84[72]$. 
més ni menys com a plena pietat, una tan lúcida exigència de raó il-lustradas ${ }^{60}$.

I és que, sezillament - com ja hem dit, i repetirem per concloure - allò que Bloch fa sempre, fins i tot en fer història de la filosofia (medieval o qualsevol altra), és de dir-se ell mateix, de pensar $\mathrm{i}$ «re-pensar» ara i aquí allò que fou dit $\mathrm{i}$ pensat en un altre temps i que pot ser alhora rescatat per a un futur sempre nou. És, dones, en tant que filòsof que Bloch fa història de la filosofia medieval. Altrament dit, és Bloch, filòsof, qui és medievalista ( $\propto$ Bloch filosof, com a medievalista», pot llegir-se el títol d'aquest article); i alhora és en tant que fa història medieval que és també Bloch filòsof ( $«$ Bloch, filosof com a medievalista», pot llegir-se igualment l'esmentat títol).

Heus aquí la grandesa i, ensems, el límit de l'aportació de Bloch en tant que historiador del filosofar (aportació que hom pot així caracteritzar, a la vegada, com a filosòfico-històrica i històrico-fillosòfica): grandesa i límit. equivalents a la grandesa $i$ al límit que hem trobat en el fet que només foren els intermons de la història de la filosofia allò que Bloch recollís d'aquesta; grandesa i límit, a més, que tenien llur excepció si entrava en joc l'indestructible prejudici «a-teŕstic» blochià (i diem a-teístic, no «ateu») ${ }^{61}$, com s'esdevenia en el cas d'Anselm, en què hom havia de parlar de la hipòstasi Déu i, en fer-ho, Bloch palesava un límit, però sense cap grandesa alhora. Llevat d'això, però, cal reconèixer les aportacions de Bloch com a inqüestionablement originals, suggeridores $\mathrm{i}$ adhuc creadores, mai no neutrals $\mathrm{i}$ més aviat críticament despertes; unes aportacions que tampoc no admeten dels lectors cap actitud de neutralitat, i que més aviat n'exigeixen una de crítica i personal i, així, de no menys creadora.

60 ZW 79 [68].

61 Convencionalment volem significar per ateu aquell qui nega fins i tot el forat i l'espai buits que deixa la mort de la hipòstasi divina (T'anomenada emort de Déun), actitud que Bloch no admet en absolut com a vàlida. Per a-teístic, en canvi, entenem aquell qui nega únicament aquesta hipòstasi divina, però no el buit deixat precisament per la seva negació. I en aquest sentit s' ha d'entendre la proclama blochiana que només un ateu pot ser un bon cristià, només un cristià pot ser un bon ateu (E. BLoch, Atheismus in Christentim, ed cit.p. 15; trad. cit, p. 9). 